\title{
INTERNATIONAL STANDARDS REGULATING LABOUR OF UNDERAGE WORKERS
}

\author{
Anna Sydorenko \\ Ph.D. in Law, Assistant Professor, Poltava Law Institute \\ Yaroslav Mudryi National Law University, Ukraine \\ e-mail: gannusya1988@ukr.net,orcid.org/0000-0002-3947-3863 \\ Inna Polkhovska \\ Ph.D. in Law, Assistant Professor, Poltava Law Institute \\ Yaroslav Mudryi National Law University, Ukraine \\ e-mail: polkhovska.inna@ukr.net, orcid.org/ 0000-0003-0998-4686
}

\section{Summary}

The paper presents an analysis of the international standards governing child labour. It is determined that the right to work is every able-bodied person's inalienable and indispensable right. Under current conditions of social development, the issues of legal regulation of labour of specific categories of workers are becoming of vital importance. It is proved that their regulation is based on differentiation which is defined by the extension of children rights. It is researched that in legislation of most countries, regulation of child labour is allocated in a separate institute whose rules, to a greater extent, correspond to international standards. It is determined that all countries should take measures to protect children's rights and freedoms in the exercise of their right to work. It is proved that the acts of the European Union contain a specified list of children's rights which should be the basis for developing and enhancing national labour legislation. It is determined that labour law, as well as any field of law, is distinguish by unity and differentiation. Unity is characterized by spreading labour law rules for all workers without exception, and differentiation of legal regulation of labour is characterized by the specification of the rules governing labour of specific categories of workers. It is investigated that differentiation of child labour is based on a subjective feature and is determined by the age, physiological, psychological and social factors. It is determined that differentiation of labour of this category of workers implies providing them with additional social and labour guarantees, as well as the use of restrictions and prohibitions when performing certain types of work. It was researched that the main criterion for child labour is differentiation of their age and working conditions. Their basic requirements are established by international rules and implemented in the national legislation.

Keywords: right to work; international standards; child labour; occupational safety and health; children's rights; minimum age for admission to employment; working conditions; differentiation of child labour.

DOI: https://doi.org/10.23856/4623

\section{Introduction}

The right to work belongs to one of the main human and civil socio-economic rights; it is inalienable, recognized and enshrined in international legal acts both universally and regionally. It is also warranted by the Basic Laws of all countries without exception. This right is 
recognized by most important international acts, including the Universal Declaration of Human Rights, the International Covenant on Economic, Social and Cultural Rights, the International Covenant on Civil and Political Rights, the European Social Charter (Revised), Conventions and Recommendations of the International Labour Organization, etc.

In this way, the Universal Declaration of Human Rights provides for that everyone has the right to work, free choice of such work, just and secure working conditions and protection against unemployment (Universal Declaration of Human Rights, 1948). In turn, the International Covenant on Economic, Social and Cultural Rights recognizes the right of everyone to the opportunity to gain his living by work which he freely chooses (International Covenant on Economic, Social and Cultural Rights, 1966). The provisions of para. 1 of Art. 1 of the European Social Charter (Revised) (European Social Charter (Revised), 1996) and the Convention concerning Employment Policy, 1964 (No. 122) of the International Labour Organization (Employment Policy Convention, 1964) define responsibilities of the State to ensure effective exercise of the right to work. The main goal of the state policy is to provide everyone who is ready to work and/or is seeking employment with opportunities to obtain it. The right to work, achievement to one's capacity for work is indispensable for every person. Under current conditions of development of labour legislation, legal regulation of labour of specific categories of citizens are becoming of vital importance. Due to this, it should be noted that differentiation consists in expanding legal regulation of labour of specific categories of workers, which, in turn, allows to take into account various factors that have a direct impact on the ability of a person to achieve to his capacity in the process of work.

Under current conditions of the European integration, there is a problem of reforming the legislation in regard to social protection of the public, including employment of specific categories of workers, namely minors. The feature is that the world community is very concerned about the distribution and widespread use of child labour, which cannot be considered useful, as long as such labour is difficult and dangerous, which negatively affects the health of this category of persons, their physiological development, and also deprives them the opportunity to receive proper education, etc.

Aim. The paper is aimed at studying legal regulation of child labour by rules both internationally and in the member states of the European Union as well as identifying the main directions of reforming it.

Material and methods. The methodological basis of the paper is a set of general scientific and special methods of cognition. Using the dialectical method, the problem of exercising basic labour rights of minors is considered. The use of the comparative legal method helps to identify and compare similar components of international legal acts and legislation of foreign countries.

The empirical foundations of the study are provisions of international legal acts on rights and guarantees of minors and legislation of different countries.

\section{Results and discussion}

Problems of legal regulation and protection of child labour are of vital importance in the context of modern social development. Therefore, cases of abuse of the right by employers recruiting minors are of great concern. Recently, employers have avoided entering into employment contracts with this category of persons as employers have a number of additional responsibilities for exercising such workers' rights and guarantees in the performance of work. It should be emphasized that in legislation of most countries, regulation of child labour is allocated in a 
separate institute whose rules have to comply with international standards and provide special protection and safeguards for this category of workers (Kyselev, 1988:223-224).

Conventions of the International Labour Organization, which are the basis for the development of labour legislation in foreign countries, are of great importance for implementation of children's labour rights. Therefore, one of the approaches in the field of human rights is the need for the implementation of the European standards in the national legal systems. The issue of implementation lies, first and foremost, in the need to resolve the problem of the position of the relevant international treaties in the national legal system and their legal validity (Tatsii, 2015: 39-40). In English, "to implement" means "to make something such as an idea, plan, system, or law start to work and be used" (Macmillan Dictionary), "to give practical effect to and ensure of actual fulfilment by concrete measures" (Merriam-Webster Dictionary).

As for child labour, considerable attention has been paid to the implementation of this right by the International Labour Organization which has adopted a number of Conventions and Recommendations to ensure the right to work and its protection for this category of workers. It should be emphasized that adoption and further adherence to the Conventions and Recommendations regulating labour relations of this category of workers is one of the means of improving the legislation of the members of the International Labor Organization in protection from the use of child labour. The following Conventions should be included in the main instruments of this Organization in the field of children's occupational safety and health: the Convention concerning the Age for Admission of Children to Employment in Agriculture, 1921 (No. 10) (Minimum Age (Agriculture) Convention, 1921); the Convention concerning the Compulsory Medical Examination of Children and Young Persons Employed at Sea, 1921 (No. 16) (Medical Examination of Young Persons (Sea) Convention, 1921); the Convention Fixing the Minimum Age for the Admission of Children to Employment at Sea, 1936 (No. 58) (Minimum Age (Sea) Convention (Revised), 1936); the Convention concerning Medical Examination for Fitness in Industry of Children and Young Persons, 1946 (No. 77) (Medical Examination of Young Persons (Industry) Convention, 1946); the Convention concerning Medical Examination of Children and Young Persons for Fitness for Employment in Non-Industrial Occupations, 1946 (No. 78) (Medical Examination of Young Persons Convention, 1946); the Convention concerning the Restriction of Night Work of Children and Young Persons in Non-Industrial Occupations, 1946 (No. 79) (Night Work of Young Persons Convention, 1946); the Convention concerning the Night Work of Children and Young Persons in Industry (Revised), 1948 (No. 90) (Night Work of Young Persons (Industry) Convention (Revised), 1948); the Convention concerning the Prohibition and Immediate Action for the Elimination of the Worst Forms of Child Labour, 1999 (No. 182) (Worst Forms of Child Labour Convention, 1999); the Convention concerning the Minimum Age for Admission to Employment Underground in Mines, 1965 (No. 123) (Minimum Age (Underground Work) Convention, 1965); the Convention concerning Medical Examination of Young Persons for Fitness for Employment Underground in Mines, 1965 (No. 124) (Medical Examination of Young Persons (Underground Work) Convention, 1965).

The International Labour Organization specifically regulates the age at which a person can be admitted to employment. In this way, the Convention concerning Minimum Age for Admission to Employment, 1973 (No. 138) specifies that the minimum age for admission to employment shall not be less than the age of completion of compulsory schooling and, in any case, shall not be less than 15 years. At the same time, para. 4 of Art. 2 of the Convention establishes that a Member whose economy and educational facilities are insufficiently developed may initially specify a minimum age of 14 years, and according to para. 5 such a state shall include in its reports on the application of this Convention a statement (a) that its reason for 
doing so subsists; or (b) that it renounces its right to avail itself of the provisions in question as from a stated date (Minimum Age Convention, 1973). However, the Recommendation concerning Minimum Age for Admission to Employment, 1973 (No. 146) of the International Labour Organization emphasizes that measures should be taken to ensure that the conditions in which children and young persons under the age of 18 years are employed or work reach and are maintained at a satisfactory standard. These conditions should be supervised closely (Minimum Age Recommendation, 1973).

It should be emphasized that, in accordance with the mandate of the International Labour Organization, in the social sphere, international law, first of all, begins with protection of children and their fundamental rights. Legislative activities of the International Labour Organization aim at eliminating child labor, which violates the normal development of the child. The Organization pays special attention to the worst forms of involving children into work. The management of the aforementioned Organization has proposed a system of standards whose main purpose is to create and ensure that children in all countries, regardless of their level of development, are protected from the worst forms of work. These standards are defined by the Convention concerning the Prohibition and Immediate Action for the Elimination of the Worst Forms of Child Labour, 1999 (No. 182) (Worst Forms of Child Labour Convention, 1999). Members which ratify this Convention shall take immediate and effective measures to secure the prohibition and elimination of the worst forms of child labour as a matter of urgency. To eliminate the use of child labour, the main way is to improve the legislation and practice of the Member States of the International Labour Organization, and, in turn, their proper and unconditional compliance with the Conventions and Recommendations regulating social and labour relations.

Another, rather important international instrument regulating children's and minors' rights is the Declaration of the Rights of the Child adopted by the United Nations General Assembly on 20 November 1959 (Resolution adopted by the General Assembly 1386 (XIV) which proclaims that the best interests of the child shall be the paramount consideration and the child shall enjoy special protection. Consequently, the child shall be given opportunities and facilities to enjoy the benefits of social security including adequate nutrition, housing, medical services, education and be protected against all forms of neglect, cruelty and exploitation.

The most important international legal instrument regulating the protection of children is the Convention on the Rights of the Child adopted by the United Nations General Assembly on November 20,1989, in which the basic provisions on protection and exercising children's rights are formed. In this way, para. 2 of Art. 2 provides for that States Parties shall take all appropriate measures to ensure that the child is protected against all forms of discrimination or punishment on the basis of the status, activities, expressed opinions, or beliefs of the child's parents, legal guardians, or family members. In turn, para. 2 of Art. 3 obliges to ensure the child such protection and care as is necessary for his or her well-being. Art. 32 of the abovementioned Convention stipulates that States Parties recognize the right of the child to be protected from economic exploitation and from performing any work that is likely to be hazardous or to interfere with the child's education, or to be harmful to the child's health or physical, mental, spiritual, moral or social development.

Regarding exercising the right to work, para. 2 of Art. 32 of the Convention establishes that States Parties shall: (a) provide for a minimum age for admission to employment; (b) provide for appropriate regulation of the hours and conditions of employment; (c) provide for appropriate penalties or other sanctions to ensure the effective enforcement of the requirements (Convention on the Rights of the Child, 1989). It should be noted that implementation of these provisions shall be ensured by means of labour law of each of the States Parties. The European 
Social Charter (Revised) adopted on 3 May 1996 (European Social Charter (Revised, 1996), the Community Charter of the Fundamental Social Rights of Workers adopted on 9 December 1989 (Community Charter of the Fundamental Social Rights of Workers, 1989) and the Charter of Fundamental Rights of the European Union adopted on 7 December 2000 (Charter of Fundamental Rights of the European Union, 2000) containing the basic standards of safety of all workers, including minors, are of great importance for the development of labour law of the European Union.

In this way, Art. 7 of the European Social Charter (Revised) defines the basic children's and young persons' rights concerning their social protection, in particular, para. 1 provides for the minimum age of admission to employment that generally shall be 15 years. It is subject to exceptions for children employed in prescribed light work without harm to their health, morals or education. In turn, para. 2 of the said Article provides for that the minimum age of admission to employment shall be 18 years with respect to prescribed occupations regarded as dangerous or unhealthy (European Social Charter (Revised), 1996). An example of a violation of this paragraph is Germany, since admission to employment of persons under the age of 18 is allowed in the sectors of trade, transport, hotel business, food, although the working conditions in these sectors are dangerous and harmful to health (Homen et al., 1988:512).

As for working hours, para. 4 of Art. 7 of the European Social Charter (Revised) provides that persons under 18 years of age shall be limited in accordance with the needs of their development, and particularly with their need for vocational training (European Social Charter (Revised), 1996). For instance, pupils deliver newspapers starting at 6 o'clock in the morning during school hours. The Committee of independent experts came to the conclusion that the pupils' rights to favourable conditions for education are violated.

Para. 5 of the said Article recognises the right of young workers and apprentices to a fair wage or other appropriate allowances, and para. 6 provides that the time spent by young persons in vocational training during the normal working hours with the consent of the employer shall be treated as forming part of the working day. Paragraphs 7, 8 and 9 of Art. 7 of the European Social Charter (Revised) should be included in the guarantees provided to underage workers. In this way, para. 7 provides that employed persons of under 18 years of age shall be entitled to a minimum of four weeks' annual holiday with pay; para. 8 provides that persons under 18 years of age shall not be employed in night work with the exception of certain occupations provided for by national laws or regulations; para. 9 provides that persons under 18 years of age employed in occupations prescribed by national laws or regulations shall be subject to regular medical control (European Social Charter (Revised), 1996). However, it should be emphasized that a shortcoming of provisions of the Charter is the absence of prohibition on involving children and young persons in employment related to cinematography, performances, advertising, which is dangerous to their moral development and can negatively affect them as individuals. It should be pointed out that rules of the European Social Charter (Revised) define the image of the European Union at the international level. The provisions specified therein shall be strictly complied with by the Union since the list of rights shall be implemented in the course of enforcing their domestic and foreign policies by member states of the European Union (Communication from the Commission, 2000).

The Community Charter of the Fundamental Social Rights of Workers adopted on 9 December 1989 is one more European instrument regulating child labour. This document ensures young people's right to receive initial vocational training of a sufficient duration to enable them to adapt to the requirements of their future working life; for young workers, such training should take place during working hours; moreover, it provides for the obligation of 
member states to take all appropriate measures to adjust labour legislation applicable to young workers so that their specific development and vocational training and access to employment needs are met. In particular, according to para. 22 of the Charter, the duration of work shall, in particular, be limited - without it being possible to circumvent this limitation through recourse to overtime - and night work prohibited in the case of workers of under 18 years of age, save in the case of certain jobs laid down in national legislation or regulations (Community Charter of the Fundamental Social Rights of Workers, 1989).

The Charter of Fundamental Rights of the European Union adopted on 7 December 2000 defines the prohibition of employment of children and occupational safety and health for young people, as well as the employer's duty to create working conditions appropriate to their age, namely, in Art. 32. Moreover, the said category of workers is ensured with protection against economic exploitation and any work likely to harm their safety, health or physical, mental, moral or social development or to interfere with their education (Charter of Fundamental Rights of the European Union, 2000).

One of the main special acts regulating child labour in the European Union is the Council Directive 94/33/EC of 22 June 1994 on the protection of young people at work (Directive 94/33/ $E C, 1994)$. The said Directive establishes special legal guarantees of work of this category of persons, namely: the minimum working or employment age not lower 15 years; guaranteeing that young people have working conditions which suit their age; the employer's duty to inform young people and their legal representatives of possible risks; an appropriate free assessment and monitoring of their health at regular intervals; prohibition of work which is objectively beyond young people's physical or psychological capacity; limitation of the working time of children to eight hours a day and 40 hours a week; prohibition of work by adolescents either between 10 p.m. and 6 a.m. or between 11 p.m. and 7 a.m.; entitlement of adolescents to a minimum rest period of 12 consecutive hours for each 24-hour period; entitlement of young people to a break of at least 30 minutes where daily working time is more than four and a half hours; providing with a period free of any work in the school holidays of children subject to compulsory full-time schooling; allowing the adolescents equivalent compensatory rest time within the following three weeks if their work was used to prevent negative consequences and other circumstances (Directive 94/33/EC, 1994).

Furthermore, Art. 5 of the Council Directive 91/383/EEC provides that the appropriate special medical surveillance of young workers shall extend beyond the end of the employment relationship of the worker concerned (Council Directive 91/383/EEC, 1991). The acts of the European Union contain a clear list of children's rights which should be laid down as a basis for the development of regulatory statutory acts, respected and adhered to the implementation of the domestic and foreign policies of member states of the European Union (Communication from the Commission COM, 2000).

Having analyzed the international standards of legal regulation of children labour, we would like to emphasize that children rights to work are also enshrined at the national level in all states.

Unity and differentiation are inherent to labour law as well as any field of law. Differentiation of legal regulation of labour is characterized by concrete definition of labour law rules regulating employment of specific categories of citizens. Differentiation of legal regulation of employment includes features and specifics regulating labour relations provided for by international standards, national legislation, local rules.

Admission to employment of minors is an important step for employers. To begin with, performing work under an employment contract provides for creation of guarantees for this 
category of workers. Employers should take into account the fact that minors do not have significant experience and cannot foresee all hazards and risks that may arise. In turn, employer should carry out an analysis of possible risks, take into account working conditions and adhere to special rules enshrined in labour legislation which determine the special legal status of workers, responsibilities and guarantees of this category of workers.

Differentiation of legal regulation of child labour is based on the subjective characteristics and is conditioned by the age, physiological, psychological and social factors. Taking into account a subjective factor of differentiation leads to the necessity of adhering to guarantees of young workers in comparison with other categories of workers. Differentiation of child labour involves providing them with additional social and labour guarantees, as well as application of restrictions and prohibitions when performing certain types of work. It should be noted that the age is one of the main criteria for differentiation of legal regulation of child labour. The scope of such employment and its conditions can be recognized as an additional reason.

Most countries have age limits and rules for admission to employment of minors, but the problem is that many children are still employed off the record.

In labour law, there is such a notion of legal personality which includes legal capacity and legal competence. It also entrusts a person with rights and obligations and an ability to govern them. Throughout the Western world, labour legal capacity and legal competence are usually differentiated. Legal capacity arises from the achievement of a minimum age for admission to employment, which, according to the general rule, is 15 to 16 years old. With regard to legal competence, it begins from more than 18 years old, and in a number of countries, even from the age of 21 years old (Kyselev, 1988:52-53).

International standards impose a low age of labour legal capacity, for example, 15 years old for admission to industrial work and 14 years old for work in housekeeping and agriculture. In countries such as Belgium, Italy, Japan, children are allowed to be admitted to employment from 14 years of age, and in some countries even from 12 years of age to perform so-called "light labour" (Iran, Portugal, India, Mexico, etc.). In our opinion, the abovementioned age for admission to employment is low which violates children's rights to education, healthy growth, childhood.

Admission to employment of an underage person should only take place with the consent of his parents or persons replacing them. In some countries, consent of parents is necessary for entering into all or some types of employment contracts before young people reach legal age. This is substantiated by the fact that adolescents need protection of their interests, occupational safety and health, provision with appropriate guarantees, which, first of all, should be relied upon on their parents.

Describing the age as the main basis for the subjective differentiation of legal regulation of child labour, we believe that rules that ensure exercising the right to work of this category of persons should be mentioned and illustrated by an example of different countries.

In this way, according to the French legislation, namely the Labour Code of France, it is prohibited to employ children before they finish school, namely, before they reach 16 years of age, exceptions are school holidays for persons over 14 years old which is subject to a number of requirements. An employment contract will only be valid if it is executed in French in writing (Code du travail,2008).

Specific age limits and guarantees are also defined in the German legislation. The main provisions of occupational safety and health are contained in the Occupational Safety Act. The Basic Law for the Federal Republic of Germany (Basic Law for the Federal Republic of Germany, 1949) prohibits employment of children under 13 years of age. In turn, the minimum 
age for admission to permanent employment is 15 years of age. Persons who work before they reach the age of 15 years of age can to achieve to their capacity to work during non-study time of less than three hours a day. The indispensable condition of admission to employment is availability of a medical certificate. In turn, young persons aged 15 to 18 years of age have the right to work for no more than 40 hours a week and eight hours a day. Vacation time is granted in a differentiated way, depending on a worker's age, namely 30 calendar days for workers who are 15 years of age, 27 calendar days for those who are 16 years of age and 25 calendar days for those who are 17 year of age. It is difficult to dismiss an underage person as such a dismissal shall be duly substantiated and warranted by law.

Describing child labour in Poland, it should be noted that Art. 190 of the Labor Code of the Republic of Poland (Polish Labour Code, 1997) defines that a young person is a person who has reached the age of 16 , but is not yet 18 . There is a prohibition to employ young people who have not yet reached the age of 16. It is only possible to employ a young person who has completed at least basic secondary school and presents a medical certificate declaring that work of a given kind does not endanger his health.

In Estonia, legal regulation of child labour is carried out by the Employment Contracts Act (Employment Contracts Act Republic of Estonia, 2009). When employing children, laws imposing strict restrictions and rules regarding employment of young people are often an obstacle. In this way, in compliance with the abovementioned Act, an employer shall not enter into an employment contract with a minor under 15 years of age. Exceptions are jobs where duties are simple and do not require any major physical or mental effort, so an employer may enter into an employment contract with a minor of 13-14 years of age. Minors of 7-12 years of age are allowed to do light work in the field of culture, art, sports or advertising. The guaranty of children labour is observance of working time, namely, in the case of an employee who is 7-12 years of age, full-time work means 3 hours a day and 15 hours over a period of seven days; in the case of an employee who is 13-14 years of age or subject to the obligation to attend school -4 hours a day and 20 hours over a period of seven days; in the case of an employee who is 15 years of age and not subject to the obligation to attend school - 6 hours a day and 30 hours over a period of seven days; in the case of an employee who is 16 years of age and not subject to the obligation to attend school, and an employee who is 17 years of age - 7 hours a day and 35 hours over a period of seven days (Employment Contracts Act Republic of Estonia, 2009).

In the UK, the law allows admission to employment people who are at least 12 years of age. However, they cannot work more than 3 hours a day. The labour guarantee is that such persons cannot be involved in harmful work, work in the night shift and in shift impeding the attendance of school.

In the United States of America, a person is legally admitted to employment at the age of 16 years, although as a contingency measure, persons who are 14 years of age are admitted to employment in non-industrial areas. It should be emphasized that in a number of countries, generally, there is no prohibition of night work for children and adolescents (e.g. Japan, Austria, Spain, etc.).

Summarizing the characteristics of such a reason for differentiation as the age, it should be noted that in each country, in accordance with the law, the minimum age for admission to employment of a minor is established and guarantees provided to him are defined. In our opinion, a shortcoming is that often the relevant minimum age for admission to employment is not observed which gives rise to violation of the rights and interests of a specific category of persons. 
With reference to the issue of ensuring the working conditions of minors, we would like to point out that they should differ from the working conditions of adult workers. First of all, it is explained by the physiological characteristics of a child and adolescent body, as well as the fact that a major part of such persons does not have a profession and speciality. Although, at the legislative level, it is determined that minors are equated to adults in labour rights, at the same time they are subject to certain safeguards in regard of occupational safety and health, working time, rest time.

In relation to the issue of normative consolidation of the notion of working conditions, the main international rules are: the International Covenant on Economic, Social and Cultural Rights, the European Social Charter (Revised), the Convention concerning Occupational Safety and Health and the Working Environment, 1981 (No. 155) of the International Labour Organization, the Recommendation concerning Occupational Safety and Health and the Working Environment, 1981 (No. 164), etc.

In this way, for instance, in some countries, it is prohibited to use child labour at weekends and on holidays, in harmful, difficult and dangerous jobs, in underground work and in jobs that are contrary to the moral standards; limits on raising heavy things are set for this category of workers, etc.

In the world community, they are different ways to remuneration of child labour. In most countries, there are guaranteed minimum wages, and in a number of countries, these are lower than for adult workers. For example, in France, for people under 17 years of age, wages are 20 percent lower and for people between 17 and 18 of age - 10 percent lower. In Belgium and Luxembourg, the minimum wage scale is determined by the age. In Japan, remuneration depends on the length of service; persons employed immediately after leaving school, lyceum or university rank as the lowest grade.

So, summarizing, we can say that the working conditions for minors and remuneration for child labour are considered and determined by differentiation depending on a number of factors.

Underage workers are a special group of workers and many factors affect their work, a risk of an accident at work. They influence physical, psychological and emotional development, educational level, professional skills, work and experience. The International Labour Organization prepared a report on the World Day for Safety and Health at Work in 2018 which is designed to form a safe and healthy generation. The Report "Improving the Safety and Health of Young Workers" provides insights on how to prevent the risk factors that may occur to workers under 15 years of age, namely, they can be inherent to their age (e.g., stage of physical, psychosocial and emotional development). Relative lack of skills, being in transition between school and work, nature of the work (i.e. shift work, part-time work, and short term, seasonal and on-call work), work characteristics (i.e. work presenting physical, chemical, biological, mechanical and psychosocial risk factors) should also be attributed to the behaviour that generates risk factors (Improving the Safety and Health of Young Workers, 2018).

\section{Conclusions}

The basic labour rights and freedoms of underage workers are an integral part of international law. Having analysed these rules, we can talk about a whole range of minors' rights relied on states to implement. However, in the modern world, the problem is that these rules are often not followed. Comparative legal analysis of international labour rules and labour legislation of some states gives grounds to assert that the legislation does not fully correspond to 
the public development. Taking into account the practice of international regulation of the legal status of a child, it should be pointed out that child labour is harmful and dangerous enough for their physiological, intellectual and spiritual development. Legal regulation of child labour is characterized by differentiation which determines the age of a person as one of its main reasons. By international standards, the minimum age for admission to employment is, according to the general rule, 15 years, which, in our opinion, is low and, at least, it should be 16 years of age for a person to exercise the right to work, since employment before this age prevents him from obtaining appropriate education. The duration of working hours of 40 hours per week should apply only to persons reaching the age of 18 years. Summing up the above, we can say that minors actively exercise their right to work, primarily to earn a profit and provide their own needs. With the public development and implementation of legal reforms worldwide, international standards should be revised and amended toward more full protection of labour rights and freedoms of minors in order to be implemented in the rules of national legislation as soon as reasonably possible.

\section{References}

Basic Law for the Federal Republic of Germany (1949).

Charter of Fundamental Rights of the European Union (2000).

Code du travail (2008).

Communication from the Commission "On the Chapter of Fundamental Rights of the European Union” COM (2000) 559 final. Brussels, p. 4.

Community Charter of the Fundamental Social Rights of Workers (1989).

Convention on the Rights of the Child (1989).

Council Directive 91/383/EEC (1991).

Directive 94/33/EC - Young Workers (1994).

Employment Contracts Act Republic of Estonia (2009).

Employment Policy Convention (1964).

European Social Charter (Revised)(1996).

Homen D., Kharrys D., Zvoak L. (1988). Evropeiskaia Konventsyia o pravakh cheloveka y Evropeiskaia Sotsyalnaia Khartyia: pravo y praktyka [European Convention on Human Rights and the European Social Charter: law and practice].Moscow: MNUYMP [in Russia].

Improving the Safety and Health of Young Workers (2018).

International Covenant on Economic, Social and Cultural Rights (1966).

Kyselev Y.Ia. (1988) Zarubezhnoe trudovoe pravo. Uchebnyk dlia vuzov [Foreign labor law. Textbook for universities]. Moskva: NORMA-YNFRA-263p. [in Russia].

Kyselev Y.Ia. (1999) Sravnytelnoe y mezhdunarodnoe trudovoe pravo. Uchebnyk dlia vuzov [Comparative and International Labor Law. Textbook for universities]. Moskva: Delo - 728p. [in Russia].

Macmillan Dictionary. URL: https://www.macmillandictionary.com/dictionary/british/implement_1.

Medical Examination of Young Persons (Industry) Convention(1946).

Medical Examination of Young Persons (Sea) Convention (1921)

Medical Examination of Young Persons (Non-Industrial Occupations) Convention (1946).

Merriam-Webster Dictionary. URL: https://www.merriam-webster.com/dictionary/implement.

Minimum Age (Agriculture) Convention (1921).

Minimum Age Convention (1973). 
Minimum Age Recommendation (1973).

Minimum Age (Sea) Convention (Revised),(1936).

Minimum Age (Underground Work) Convention (1965).

Medical Examination of Young Persons (Underground Work) Convention (1965).

Night Work of Young Persons (Industry) Convention (Revised), (1948).

Polish Labour Code (1997).

Night Work of Young Persons (Non - Industrial Occupations) Convention (1946).

Occupational Safety and Health Convention (1981).

Occupational Safety and Health Recommendation (1981).

Resolution adopted by the General Assembly 1386 (XIV). Declaration of the Rights of the Child.

Tatsii V.Ia. (2015) Vybrani statti, vystupy, interviu [Selected articles, speeches, interviews]

Kharkiv: Pravo-648p. [in Ukrainian].

Universal Declaration of Human Rights (1948).

Worst Forms of Child Labour Convention (1999). 